\title{
Genotypic variation does not explain differences in growth of mummichogs Fundulus heteroclitus from simple and complex tidal marsh landscapes
}

\author{
R. T. Kneib* \\ The University of Georgia Marine Institute, Sapelo Island, Georgia 31327, USA
}

\begin{abstract}
Decimal coded wire tags were used to measure individual growth rates of mummichogs (Pisces: Fundulidae) within tidal marshes on Sapelo Island, Georgia, USA. Mummichogs $(\mathrm{n}=17508)$ were marked and released at 3 sites with different levels of complexity in their tidal channel drainage networks. The proportion of recaptures (average 19\%), which varied from 6.4 to $43.3 \%$ among sites and release dates, was inversely related to relative complexity of the tidal drainage networks. Gender-specific differences were detected in size metrics and growth rates. Mean $( \pm$ SD) growth rates ( $\mathrm{mm} \mathrm{d}^{-1}$ total length, TL) of individuals at large for 28 to $56 \mathrm{~d}$ prior to recapture ranged from $0.062 \pm 0.044$ to $0.274 \pm 0.060$ for males and $0.071 \pm 0.036$ to $0.279 \pm 0.062$ for females, with the least and most rapid growth rates associated with complex and simple tidal drainage networks, respectively. A 'common garden' experiment was conducted to test the hypothesis that there were genotypic differences in growth potential seemingly associated with landscape structure. Two size classes (40-50 and 55-65 mm TL) of individually marked mummichogs from drainage networks characterized as simple (high growth) and complex (low growth) were raised in the laboratory for $42 \mathrm{~d}$ on each of 2 daily rations (10 and $30 \%$ wet body mass) of minced fresh-frozen grass shrimp. There was no significant difference in mean $( \pm \mathrm{SD})$ daily growth rates of mummichogs from the 2 sites (simple: $0.283 \pm 0.124$ and complex: $0.299 \pm 0.131$ ) when reared under the same conditions. Although there was no evidence of a genotypic difference in growth potential between these local populations of mummichogs, a possible association between landscape structure and gene expression reflected in the spatial variation of fish growth within tidal marsh ecosystems remains to be explored.
\end{abstract}

KEY WORDS: Coded wire tags $\cdot$ Estuary $\cdot$ Genome $\cdot$ Fundulus heteroclitus $\cdot$ Killifish $\cdot$ Mummichog $\cdot$ Wetlands

Resale or republication not permitted without written consent of the publisher

\section{INTRODUCTION}

Linking spatial patterns with ecological processes at multiple scales is a central goal of landscape ecology (Turner 1989), but has also become a focus in studies of populations and communities as ecologists embrace the complexity and consequences of ecological interactions (Agrawal et al. 2007). Recent studies have demonstrated that variation in abundance, movement, and production of estuarine nekton (e.g. fishes and shrimps) populations can be associated with the relative complexity of spatial patterns in the tidal channel networks of intertidal marsh landscapes (Kneib 2003, Webb \& Kneib 2002, 2004). Given the apparent existence of a relationship between nekton production and spatial patterns in the tidal marsh (e.g. Kneib 2003), some component of production (e.g. survival and/or growth) should be responsive to variation at the landscape scale. Such a response in individual growth rates might also suggest a linkage with individual variation in physiological responses at the level of the genome.

A genetic basis for spatially-explicit phenotypic variation in freshwater fish populations is beginning to emerge (e.g. Adams \& Huntingford 2004) even among sub-populations that are not geographically isolated. For example, Adams et al. (2006) reported distinct differences at multiple microsatellite loci in sub-populations of the Arctic char Salvelinus alpinus from 3 closely connected lakes in Scotland. The authors proposed strong site fidelity, particularly in connection 
with spawning areas, as a likely mechanism producing genetic and phenotypic population sub-structuring from limited gene flow among locations even in the absence of effective physical barriers to movement.

The research reported in this paper begins to explore the issue of whether spatial variation at a landscape scale is reflected in biotic variation at the molecular level (i.e. genetic variation or variation in gene expression) within estuarine organisms. In this study, spatial variation in the complexity of tidal marsh channel networks was used as a metric of estuarine landscape structure, and individual growth rates within populations of the mummichog Fundulus heteroclitus was a metric of phenotypic variation that could reflect spatial variation in the genome.

Populations of Fundulus heteroclitus are resident year-round in marshes along most of the Atlantic coast of North America, where 2 sub-species seem to divide the range $(F . h$. macrolepidotus northward of Chesapeake Bay, and F. h. heteroclitus southwardi Morin \& Able 1983). The mummichog is a relatively small (adult size $<12 \mathrm{~cm}$ ) species found primarily along shallow estuarine shorelines (Bigelow \& Schroeder 1953). It is not a strong swimmer and has a limited home range of less than $1 \mathrm{~km}$ (Skinner et al. 2005, Able et al. 2006). Spawning and primary nursery habitats are in the intertidal zone (Kneib 1997). Because there is no planktonic larval stage, in situ differences in growth rates of individuals from different tidal marsh landscapes could reflect either inherent differences (e.g. genotypic variation or variation in gene expression affecting behavior, physiology, and metabolism) or site-specific differences in habitat quality (e.g. food availability, predation risk, temperature variation).

This study compared in situ individual growth rates of mummichogs (Fundulus h. heteroclitus) from populations resident in portions of a Georgia (USA) salt marsh landscape characterized by simple and complex tidal channel networks. Mummichogs from populations that demonstrated distinct differences in field growth rates were raised in the laboratory under identical conditions to determine whether genotypic variation in the population sub-structure within the landscape was a plausible explanation for spatially-explicit variation in growth.

\section{MATERIALS AND METHODS}

Study sites. All sites were within the Sapelo Island National Estuarine Research Reserve, which is located in an area along the Georgia (USA) coast that has a relatively low human population density. Sapelo Island has fewer than 100 permanent human residents in an area comprising ca. 4400 ha of upland adjacent to ca.
2300 ha of tidal marsh (i.e. population density of 1 person per $67 \mathrm{ha}$ ) and so, at least currently, remains among the relatively few estuarine environments minimally impacted by human development. This situation provides the opportunity to assess responses of living resources to variation within a relatively natural landscape - an increasingly rare 'control' for assessing the impact of anthropogenic alterations in other estuaries.

Relationships between the complexity of tidal channel networks, relative elevation of adjacent intertidal marshes, and distance from large tidal channels were recognized on Sapelo Island over a half century ago (Ragotzkie 1959). Salt marshes considered to be in an early stage of development have complex tidal channel networks occupying a relatively lower elevation than 'older' marshes, which are perched higher in the intertidal zone and are incised by fewer channels (Frey \& Basan 1978). Marshes closest to large channels tend to have relatively simple drainage networks and are not as extensively flooded as are marshes located in headwaters farther from major tidal channels (Ragotzkie 1959).

Mummichogs were collected from intertidal marsh creeks at 3 sites on Sapelo Island, Georgia, USA (Fig. 1), during April 2004 to August 2006. Two sites $\left(D_{\text {simple }}\right.$ and $\left.D_{\text {complex }}\right)$ were chosen initially to represent relatively simple and complex patterns of tidal channel networks within the marsh-estuarine landscape of the study area. The third site $\left(\mathrm{O}_{\text {complex }}\right)$ was added beginning June 2005 to test the hypothesis that mummichog growth rates were affected by proximity to the open estuary (i.e. Doboy Sound) as an alternative to the proposed contention that growth varied with relative complexity of marsh landscape structure.

$\mathrm{D}_{\text {simple }}$ and $\mathrm{D}_{\text {complex }}$ were located, respectively, in the lower $\left(31^{\circ} 24.919^{\prime} \mathrm{N}, 81^{\circ} 17.829^{\prime} \mathrm{W}\right)$ and upper $\left(31^{\circ} 29.379^{\prime} \mathrm{N}, 81^{\circ} 15.813^{\prime} \mathrm{W}\right)$ reaches of the Duplin River, a tidal lagoon that branches from Doboy Sound and drains approximately $11 \mathrm{~km}^{2}$ of intertidal and subtidal estuarine-marsh habitat on the west side of Sapelo Island. The entire tidal drainage of the Duplin River marshes was mapped in detail by Wadsworth (1980). The distance between $D_{\text {simple }}$ and $D_{\text {complex }}$ was ca. $9 \mathrm{~km}$. $\mathrm{O}_{\text {complex }}\left(31^{\circ} 24.650^{\prime} \mathrm{N}, 81^{\circ} 17.264^{\prime} \mathrm{W}\right)$ was ca. $1 \mathrm{~km}$ to the east of $D_{\text {simple }}$ in a smaller marsh system drained by Oakdale Creek that also branched from Doboy Sound.

Landscape complexity was measured as the linear amount of tidal channel edge within an area of $125664 \mathrm{~m}^{2}$ (circle with $200 \mathrm{~m}$ radius) at each sampling site. The channel edge values in Fig. 1 were derived from data presented in a previously published study that included the same physical sites (see Table 2 in Kneib 2003, in which LD1 $=\mathrm{D}_{\text {simple }}$ LD2 $=\mathrm{O}_{\text {complex }}$, and $\mathrm{UD} 2=\mathrm{D}_{\text {complex }}$ ). If the landscape complexity values are 

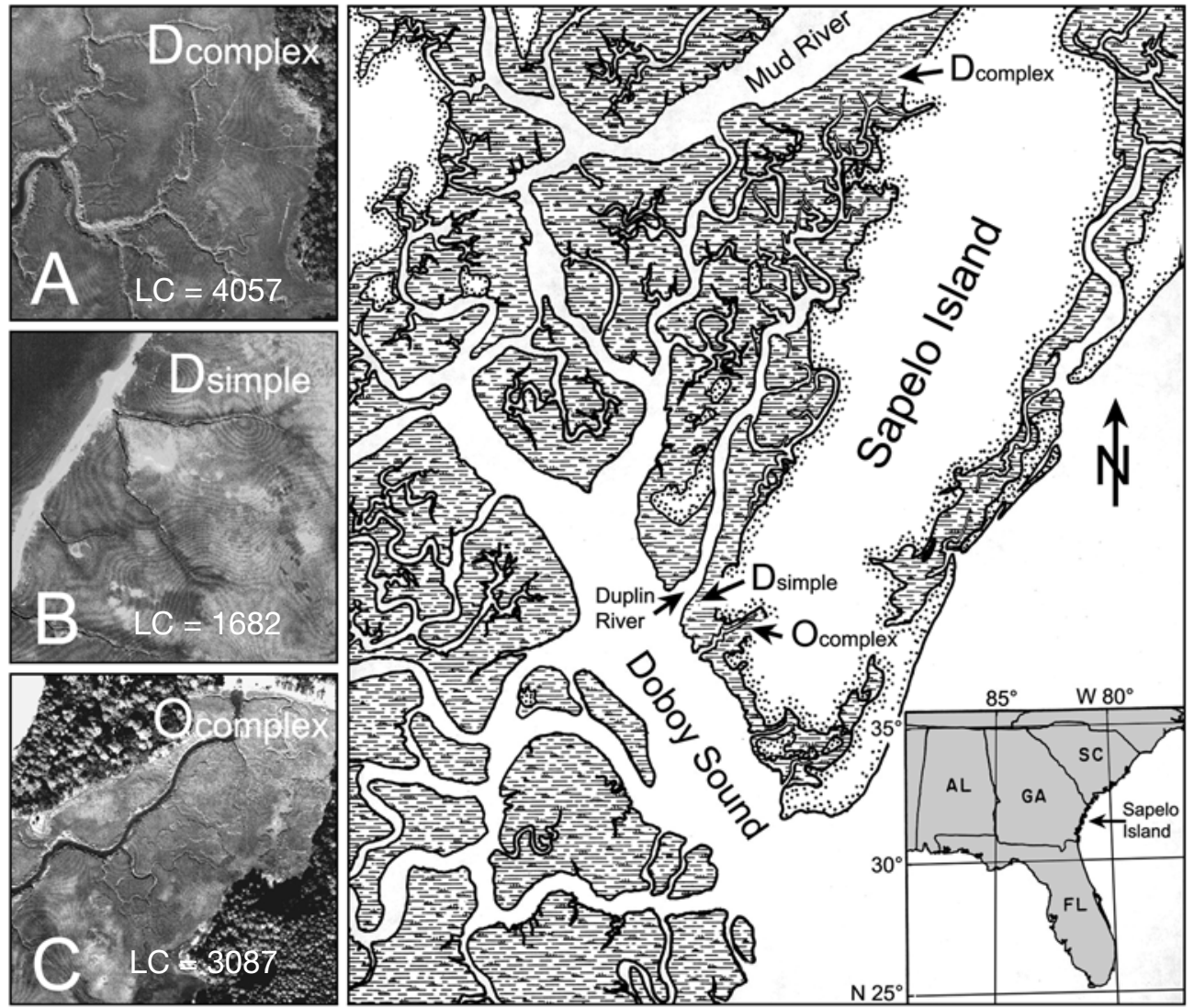

Fig. 1. Sapelo Island, Georgia, USA, showing locations of sites $\mathrm{D}_{\text {complex, }} \mathrm{D}_{\text {simple, }}$ and $\mathrm{O}_{\text {complex }}$ with aerial photos (A, B, and C) showing levels of landscape complexity (LC) for 16 ha at each site. Values for the LC metric shown here are the average linear amounts of tidal channel (intertidal + subtidal) edge within areas of $125664 \mathrm{~m}^{2}$ (circle with $200 \mathrm{~m}$ radius), and were derived from data presented in a previously published study that included the same physical sites (see Table 2 in Kneib 2003)

standardized such that $\mathrm{D}_{\text {complex }}$ is considered the maximum (i.e. complexity $=100 \%$ ), then the relative levels of complexity at $\mathrm{O}_{\text {complex }}$ and $\mathrm{D}_{\text {simple }}$ are 76 and $41 \%$, respectively.

Field growth rates. Mummichogs were captured from each site in unbaited, Gee® cylindrical wire mesh minnow traps that were placed on the bottom of intertidal creek channels for 60 to 120 min during the early stages of incoming tides (see Kneib \& Craig 2001). Traps were fished in groups of 5 to 10 at 2 to 4 locations within each tidal channel depending on channel width and complexity of the channel network. Water temperature, salinity, and dissolved oxygen (DO) were measured with a YSI Model 85 multi-purpose meter whenever traps were set. Mummichogs were counted, and a subset from each site was measured (total length [TL] = tip of the snout to end of caudal fin, and standard length $[\mathrm{SL}]=$ tip of snout to end of vertebral column), and internally marked with ferro-magnetic wire tags (1.1 $\mathrm{mm}$ in length, $0.25 \mathrm{~mm}$ diameter, Northwest Marine Technology [NMT]; Fig. 2) prior to release at the same site.
The digitally coded wire tags (DCWTs) in this study were sequentially numbered and supplied on continuous spools, each containing 10000 unique code combinations (Fig. 2). A hand-held multi-shot tag injector (NMT) was used to cut DCWTs to length, as well as magnetize and inject them in a single operation. A portable magnetometer (V-detector, NMT) was used to identify recaptured individuals with implanted DCWTs. Fish were marked by injecting DCWTs just under the skin ventro-laterally of the dorsal fin so that the tags were visually detectable when marked fish were examined under a binocular microscope at $6 \times$ magnification. This facilitated tag removal without the need to sacrifice recaptured fish. Marked fish were anesthetized with tricaine methanesulfonate (Finquel® MS-222, Argent Chemical Laboratories), and the DCWTs removed with forceps after a shallow incision in the skin was made with a scalpel. Numbered codes on DCWTs were read with the aid of a binocular microscope at $50 \times$ magnification.

It was impractical to read large numbers of DCWTs prior to their injection into the fish, so in order to iden- 




Fig. 2. Digitally coded wire tag (DCWT) used to mark mummichogs in this study. Lines of data imprinted on the $1.1 \mathrm{~mm}$ long, $0.25 \mathrm{~mm}$ diameter tag are identified in this photo-micrograph. Note that data lines are imprinted around the circumference of the tag. The beginning of the tag sequence is indicated by the flag above the ' 0 ' of the unique sequential number, and each tag usually includes portions of data lines from adjacent tag sequences

tify individuals upon recapture it was necessary to retain an archive tag for each marked fish. This was accomplished by injecting every other tag into a vertical strip of clear Silicon II sealant (GE®) applied to a waterproof data sheet (Rite-in-the-Rain®, JL Darling Corporation) on which was recorded the sex and size of each marked fish. These archival tags provided a crucial link with marked individuals and the records of their sex and initial sizes. Maintaining a permanent association between size records and the numerical sequence of tags was crucial to subsequent identification of recaptured mummichogs.

Mummichogs were marked and released on 4 occasions in each of 2 yr (May to September 2004, and April to September 2005). The gender of all marked and recaptured individuals was recorded but there was no attempt to control for the number of each sex that was marked or recaptured. No fish were marked at the $\mathrm{O}_{\text {complex }}$ site in 2004. Scheduling conflicts sometimes precluded the marking and release of fish at all 3 sites in 2005, when marked individuals were released on only 3 occasions at 2 of the sites $\left(\mathrm{D}_{\text {simple }}\right.$ and $\left.\mathrm{O}_{\text {complex }}\right)$. Efforts to recapture marked individuals using unbaited minnow traps (30 to 60 min soak times) on incoming tides occurred at intervals of 1 to $42 \mathrm{~d}$ at each site; the median sampling interval was $6 \mathrm{~d}$. Recaptures that occurred within $6 \mathrm{~d}$ of the release of a new group of marked individuals were usually re-released without removing the DCWTs. Sampling to recapture marked mummichogs continued at each site until August 2006, but only individuals that were at large for 28 to $56 \mathrm{~d}$ were used in this portion of the study. This allowed suf- ficient time for absolute growth in length to exceed measurement error $( \pm 1 \mathrm{~mm})$ but also preserved some of the temporal variability in short-term growth rates within years.

Laboratory growth experiment. Growth rates of mummichogs from the $\mathrm{D}_{\text {simple }}$ and $\mathrm{D}_{\text {complex }}$ sites were compared under common conditions in the laboratory from 12 September to 24 October 2005 (42 d duration). The experiment was conducted at the University of Georgia Marine Institute in a laboratory building where temperature was allowed to fluctuate with outside ambient conditions. Natural light from 4 windows was augmented with overhead fluorescent lighting controlled by a timer to provide a $14 \mathrm{~h}$ light:10 h dark diel cycle. Estuarine water from a nearby tidal creek (South End Creek) was pumped continuously into an above-ground holding tank before passing by gravityfeed to 3 wet tables in the building. Each table held eight to nine 761 rectangular glass tanks $(75 \times 32 \times$ $30 \mathrm{~cm}$ deep), which were individually supplied with a continuous flow of water from above. Each tank was an independent flow-through system that drained from the bottom and included a standpipe to maintain the water volume at 38 to 461 (ca. 50 to $60 \%$ of capacity); water was continuously aerated by pumping compressed air through air-stones submerged in each tank. Wood-frame screen covers (0.5 mm mesh) were placed on top of the tanks to prevent fish from leaping out during the experiment.

One tank, which did not receive mummichogs, was set up in the system to monitor temperature and DO levels during the experiment. These variables were measured at $10 \mathrm{~min}$ intervals and recorded as hourly averages using a Starlogger® Model 6004C (Unidata America) datalogger equipped with a Unidata Model 6507 thermistor-type temperature probe and a Unidata Model 7422A DO probe. Salinity of the estuarine water flowing into the experimental tanks was measured once daily with a YSI Model 85 meter (DO/conductivity/salinity/temperature).

The experimental design included 3 factors, each with 2 levels: Site $\left(\mathrm{D}_{\text {simple }}\right.$ and $\left.\mathrm{D}_{\text {complex }}\right)$, Size class (mummichogs 40-50 and 55-65 mm TL), and Ration ( 10 and $30 \%$ of wet body mass $d^{-1}$ ). Each of the 8 treatment combinations had 3 replicates (24 tanks). A replicate consisted of 10 mummichogs ( 5 males, 5 females) from the appropriate site and initial size class. Each of the 240 individual mummichogs in this experiment was marked with a unique DCWT as described earlier. Mummichogs that were lost (i.e. mortality or escape) in the course of the experiment were replaced immediately with marked individuals of approximately equal size. These replacements were intended to maintain a constant density of mummichogs in each tank, but were excluded from the calculation of growth rates. 
Individual mummichogs were measured (TL and SL) to the nearest $\mathrm{mm}$, and all 10 individuals from each tank were weighed as a group to the nearest $0.1 \mathrm{~g}$ at weekly intervals until the experiment was terminated. The batch wet mass values were used to adjust the daily food ration for growth at weekly intervals. Ration size (10 or $30 \%$ of wet mass) was determined from the batch wet weight of mummichogs in each of the 4 Size $\times$ Ration treatment combination averaged across Sites and replicates $(\mathrm{N}=6)$. Thus, mummichogs from both sites always received the same amount of food.

Mummichogs were fed a diet of daggerblade grass shrimp Palaemonetes pugio, a natural prey item that was collected weekly from nearby tidal creeks. Fresh grass shrimp were coarsely chopped in an electric food chopper and quantities equivalent to one-half of a daily food ration were weighed and apportioned into the individual chambers of plastic ice cube trays, which were then filled with fresh water and frozen. This was not only a convenient way of storing a week of fresh-frozen food, but was also an effective method of delivering rations to each tank. Individual ice cubes containing the appropriate food ration were placed in the experimental tanks twice daily (morning and afternoon). Food particles slowly became available to the mummichogs in the tank as the ice melted (usually in 5 to $10 \mathrm{~min}$ ), which helped to ensure a relatively even distribution of the ration among the experimental subjects. Tubes delivering water and air to the experimental tanks were removed for 20 to $30 \mathrm{~min}$ during these feeding sessions to ensure that the food was not carried out of the tanks through the stand pipes.

Statistical analyses. Statistical procedures were performed using the computer software package SYSTAT® (version 11, SPSS). The principal response variables were initial size at marking and daily absolute growth rates $\left(\mathrm{mm} \mathrm{d}^{-1}\right)$, based on changes in TL. Analyses based on changes in SL were performed, but because findings and conclusions were unaltered, they are not provided here.

There were significant gender-specific differences in size and growth metrics (Table 1), and because the sexes were not equally represented among the recaptured mummichogs (741 males: 823 females), they were analyzed separately. Field growth rates also varied within and among sites, dates, and initial sizes. Variance heterogeneity in the relationship between growth and initial size was sufficient among sites (males: $F_{\max }=2.92$, $\mathrm{df}=158, \mathrm{p}<0.01$; females: $F_{\max }=2.55, \mathrm{df}=111, \mathrm{p}<0.01$ ) to preclude a complete analysis of covariance to test for site-specific differences among slopes and mean growth rates adjusted for initial total length. Therefore, an alternative approach to analysis of field growth rates used $t$-tests, which are moderately robust even when the underlying assumptions of parametric analyses (i.e. normality and equality of variances) are not strictly met (Zar 1996). Differences in mean growth rates of marked mummichogs recaptured from the field sites were compared with $t$-tests using separate variance estimates (i.e. unequal variances assumed). Separate $t$ tests were performed to determine if there were significant differences between mean growth rates of marked mummichogs released at different sites during the same month in each year. Tests were limited to a priori comparisons of specific 2 site combinations. Growth rates of mummichogs released at $\mathrm{D}_{\text {complex }}$ and $\mathrm{D}_{\text {simple }}$ were compared to test for differences associated with landscape complexity (8 tests), and growth rates at $\mathrm{O}_{\text {complex }}$ were compared to those at $D_{\text {complex }}$ to test for possible effects associated with distance from the open estuarine waters of Doboy Sound (3 tests) for each sex. Mean initial sizes of mummichogs marked at each site were compared using the same groupings of $t$-tests to address the possibility that site-specific differences in growth rates were simply related to differences in initial sizes of mummichogs at each site. Evidence of some variance heterogeneity was detected in mean initial sizes among sites (males: $F_{\max }=1.40, \mathrm{df}=160, \mathrm{p}<0.05$; females: $F_{\max }=$ 1.48 , df $=301, \mathrm{p}<0.01$ ), so tests were conducted on the assumption that variances were unequal.

A 3-way analysis of variance (ANOVA) was used to test for effects of fixed factors (Site, Size class, Ration) and interactions on mummichog growth from the laboratory experiment. The principal response variable was absolute growth rate $\left(\mathrm{mm} \mathrm{d}^{-1}\right.$ based on TL) after $42 \mathrm{~d}$. Sexes were equally represented in each replicate of the laboratory experiment, so it was unnecessary to conduct gender-specific tests. However, a separate 3- 
way ANOVA was performed to test for significant differences in initial size (TL) among replicate tanks that could have affected growth rates at the end of the experiment. In these analyses, average individual growth rate of the surviving mummichogs (or average initial size) within each tank was used as a replicate to avoid issues associated with pseudo-replication (Hurlbert 1984). Consequently, the ANOVAs included a total of $23 \mathrm{df}(24$ tanks - 1).

\section{RESULTS}

\section{Recaptures and field growth rates of marked individuals}

In total, 17508 individual mummichogs were tagged and released during May to September 2004 and April to September 2005 (Table 2). Recaptures collected through August 2006 averaged 19.0\% and ranged

Table 2. Fundulus heteroclitus. Number of mummichogs marked with coded wire tags and percent (\%) recaptured after 28 to $56 \mathrm{~d}$ at large, by location $\left(\mathrm{D}_{\text {complex }}, \mathrm{D}_{\text {simple, }} \mathrm{O}_{\text {complex }}\right.$ see Fig. 1 for locations) and release date (May 2004 to September 2005). The percent of marked mummichogs recaptured (after 3 to $519 \mathrm{~d}$ at large) through August 2006 is shown in parentheses

\begin{tabular}{|lcc|}
\hline Release date & No. marked & \% recaptured \\
\hline $\mathbf{D}_{\text {complex }}$ & & \\
12 May 2004 & 898 & $8.4(18.7)$ \\
22 Jun 2004 & 882 & $11.0(17.1)$ \\
18 Aug 2004 & 997 & $4.5(14.5)$ \\
25 Sep 2004 & 1011 & $4.4(13.0)$ \\
Subtotal (2004) & 3788 & $6.9(15.7)$ \\
28 Apr 2005 & 1000 & $6.5(13.9)$ \\
15 Jun 2005 & 1096 & $10.9(15.9)$ \\
13 Aug 2005 & 1403 & $4.6(11.1)$ \\
27 Sep 2005 & 1000 & $3.7(6.4)$ \\
Subtotal (2005) & 4499 & $6.3(11.8)$ \\
Total (2004-05) & 8287 & $6.6(13.6)$ \\
D simple & & \\
16 May 2004 & 899 & $11.3(32.6)$ \\
25 Jun 2004 & 878 & $19.9(43.3)$ \\
21 Aug 2004 & 465 & $11.2(41.5)$ \\
30 Sep 2004 & 1020 & $11.4(31.6)$ \\
Subtotal (2004) & 3262 & $13.6(36.4)$ \\
23 Apr 2005 & 1000 & $14.5(22.1)$ \\
15 Jun 2005 & 791 & $5.7(15.4)$ \\
1 Oct 2005 & 1168 & $7.3(18.1)$ \\
Subtotal (2005) & 2959 & $10.1(18.7)$ \\
Total (2004-05) & 6221 & $12.0(28.0)$ \\
$\mathbf{O}_{\text {complex } 2005}$ & & \\
10 Jun 2005 & $15.2(22.1)$ \\
9 Aug 2005 & 1000 & $4.8(9.6)$ \\
28 Sep 2005 & 1000 & $9.1(15.0)$ \\
Subtotal (2005) & 1000 & $9.1(15.0)$ \\
Total (2004-05) & 3000 & \\
& 3000 & \\
\end{tabular}

from 6.4 to $43.3 \%$ of the total marked among release dates and sites, with the highest and lowest recapture rates occurring at the sites where tidal channel networks defined the least $\left(\mathrm{D}_{\text {simple }}\right)$ and most complex $\left(\mathrm{D}_{\text {complex }}\right)$ landscapes, respectively. Some tagged mummichogs remained at large for more than $1 \mathrm{yr}$ before being recaptured, but 77 to $90 \%$ of the recaptures were collected within 3 mo of their initial release dates (Fig. 3). All 3319 recaptures were taken in the same channel network in which they were marked, so there was no evidence that marked individuals moved among sites.

Short-term field growth rates were based on a subset of the recaptured individuals (1539 total) that met the criterion set in this study for the number of days at large (28 to 56 d). Differences in the initial mean sizes of mummichogs marked and released among the sites were inconsistent between years and more pronounced among females than males (Table 3). When significant differences $(t$-tests, $p<0.05)$ in mean initial size occurred, it was usually because females were larger or males were smaller at $\mathrm{D}_{\text {simple }}$ than at $\mathrm{D}_{\text {complexi }}$ no significant differences between $\mathrm{D}_{\text {complex }}$ and $\mathrm{O}_{\text {complex }}$ sites were detected in initial sizes of mummichogs of either sex (Table 3). Both sexes showed a strong and consistent pattern of growing significantly faster at $\mathrm{D}_{\text {simple }}$ than at $\mathrm{D}_{\text {complex }}$ (Table 4 ). Growth rates of mummichogs between the 2 sites with relatively complex tidal channel networks $\left(\mathrm{D}_{\text {complex }}\right.$ and $\left.\mathrm{O}_{\text {complex }}\right)$ were not significant in 4 of 6 tests, but when they were (males in Sep/Oct 2005 and females in June 2005), growth at $\mathrm{O}_{\text {complex }}$ was intermediate to that at the other 2 sites. There was a significant inverse relationship between mean growth rates and the level of landscape complexity as defined in Fig. 1 (regression $\mathrm{r}^{2}=0.998, \mathrm{p}=$ 0.028 for males in Sep/Oct 2005; regression $r^{2}=0.996$, $\mathrm{p}=0.039$ for females in June 2005).

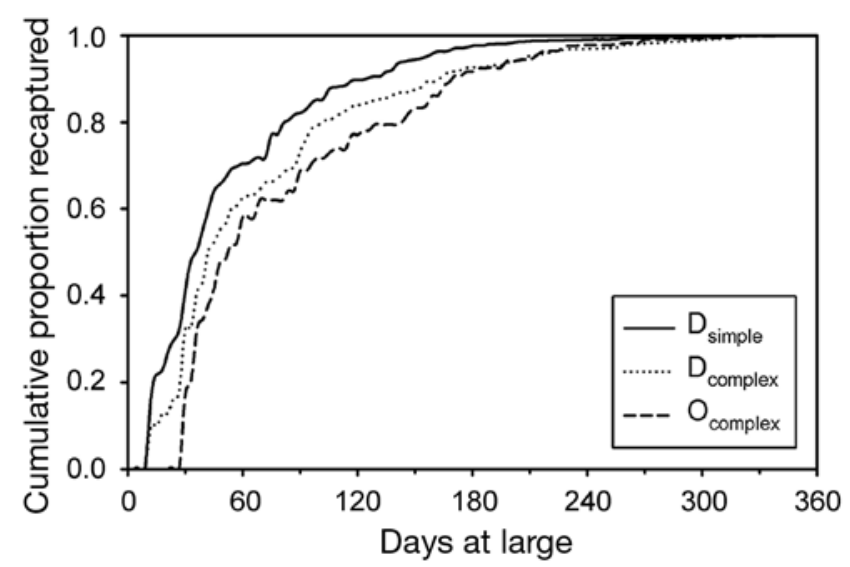

Fig. 3. Fundulus heteroclitus. Cumulative proportion of tagged mummichogs recaptured by days-at-large (days postrelease) for each of the 3 field sites $\left(\mathrm{D}_{\text {simple, }} \mathrm{D}_{\text {complex }}, \mathrm{O}_{\text {complex }}\right)$ 
Table 3. Fundulus heteroclitus. Mean \pm SD initial sizes $(\mathrm{TL}, \mathrm{mm}$ ) of recaptured male and female mummichogs marked and released at each site. $t$-tests for differences in initial mean sizes between pairs of sites $\left(D_{\text {complex }} v s . D_{\text {simple }}\right.$ and $D_{\text {complex }} v s$. $\left.O_{\text {complex }}\right)$ used separate variance estimates (i.e. unequal variances assumed). Consequently, degrees of freedom (df) were not always integers; in those cases, the df value shown was rounded down to the next smaller integer

\begin{tabular}{|c|c|c|c|c|c|c|c|c|c|}
\hline \multirow{2}{*}{$\begin{array}{l}\text { Month } \\
\text { released }\end{array}$} & \multicolumn{3}{|c|}{ - Initial size $(\mathrm{TL}, \mathrm{mm})-$} & \multicolumn{3}{|c|}{$\mathrm{D}_{\text {complex }}$ vs. $\mathrm{D}_{\text {simple }}$} & \multicolumn{3}{|c|}{$\mathrm{D}_{\text {complex }}$ vs. $\mathrm{O}_{\text {complex }}$} \\
\hline & $\mathrm{D}_{\text {complex }}$ & $D_{\text {simple }}$ & $\mathrm{O}_{\text {complex }}$ & $t$ & df & $\mathrm{p}$ & $t$ & df & $\mathrm{p}$ \\
\hline \multicolumn{10}{|l|}{ Males } \\
\hline \multicolumn{10}{|l|}{2004} \\
\hline May & $55.0 \pm 10.5$ & $56.4 \pm 10.5$ & - & 0.59 & 77 & 0.558 & - & - & - \\
\hline Jun & $51.9 \pm 8.8$ & $55.0 \pm 9.0$ & - & 1.96 & 94 & 0.052 & - & - & - \\
\hline Aug & $48.1 \pm 9.5$ & $53.1 \pm 11.0$ & - & 1.46 & 24 & 0.157 & - & - & - \\
\hline Sep & $46.4 \pm 7.4$ & $51.2 \pm 8.6$ & - & 2.31 & 42 & 0.026 & - & - & - \\
\hline \multicolumn{10}{|l|}{2005} \\
\hline Apr & $59.5 \pm 14.3$ & $56.8 \pm 11.1$ & - & 0.91 & 50 & 0.368 & - & - & - \\
\hline Jun & $57.5 \pm 9.4$ & $59.6 \pm 7.6$ & $60.1 \pm 11.0$ & 1.04 & 47 & 0.303 & 1.54 & 126 & 0.125 \\
\hline Aug & $54.1 \pm 10.7$ & - & $53.5 \pm 11.9$ & - & - & - & 0.23 & 47 & 0.821 \\
\hline Sep/Oct & $60.6 \pm 12.8$ & $54.8 \pm 9.70$ & $57.5 \pm 11.9$ & 1.83 & 28 & 0.077 & 0.83 & 39 & 0.414 \\
\hline \multicolumn{10}{|l|}{ Females } \\
\hline \multicolumn{10}{|l|}{2004} \\
\hline May & $59.5 \pm 11.0$ & $59.9 \pm 12.9$ & - & 0.19 & 85 & 0.852 & - & - & - \\
\hline Jun & $54.8 \pm 8.0$ & $60.2 \pm 8.7$ & - & 3.64 & 110 & $<0.001$ & - & - & - \\
\hline Aug & $47.5 \pm 9.5$ & $55.2 \pm 12.4$ & - & 2.57 & 41 & 0.014 & - & - & - \\
\hline Sep & $44.3 \pm 6.2$ & $54.4 \pm 7.5$ & - & 6.58 & 47 & $<0.001$ & - & - & - \\
\hline \multicolumn{10}{|l|}{2005} \\
\hline Apr & $66.2 \pm 12.5$ & $59.7 \pm 10.3$ & - & 2.72 & 50 & 0.009 & - & - & - \\
\hline Jun & $61.8 \pm 10.7$ & $59.3 \pm 9.5$ & $61.8 \pm 10.2$ & 1.08 & 43 & 0.287 & 0.03 & 115 & 0.974 \\
\hline Aug & $54.7 \pm 12.1$ & - & $54.0 \pm 11.0$ & - & - & - & 0.13 & 73 & 0.899 \\
\hline Sep/Oct & $59.6 \pm 15.1$ & $57.6 \pm 9.20$ & $56.6 \pm 8.7$ & 0.53 & 19 & 0.603 & 0.74 & 23 & 0.469 \\
\hline
\end{tabular}

Table 4. Fundulus heteroclitus. Mean \pm SD daily growth rates $\left(\mathrm{mm} \mathrm{d}^{-1}\right)$ of male and female mummichogs marked and recaptured after 28 to $56 \mathrm{~d}$ at each site. $t$-tests for differences in mean growth rates between pairs of sites $\left(D_{\text {complex }}\right.$ vs. $D_{\text {simple }}$ and $D_{\text {complex }}$ vs. $\mathrm{O}_{\text {complex }}$ ) used separate variance estimates (i.e. unequal variances assumed). Consequently, degrees of freedom (df) were not always integers; in those cases, the df value shown was rounded down to the next smaller integer

\begin{tabular}{|c|c|c|c|c|c|c|c|c|c|}
\hline \multirow{2}{*}{$\begin{array}{l}\text { Month } \\
\text { released }\end{array}$} & \multicolumn{3}{|c|}{ Growth rate $\left(\mathrm{mm} \mathrm{d}^{-1}\right)$} & \multicolumn{3}{|c|}{$\mathrm{D}_{\text {complex }}$ vs. $\mathrm{D}_{\text {simple }}$} & \multicolumn{3}{|c|}{$\mathrm{D}_{\text {complex }}$ vs. $\mathrm{O}_{\text {complex }}$} \\
\hline & $\mathrm{D}_{\text {complex }}$ & $\mathrm{D}_{\text {simple }}$ & $\mathrm{O}_{\text {complex }}$ & $t$ & df & $\mathrm{p}$ & $t$ & df & $\mathrm{p}$ \\
\hline \multicolumn{10}{|l|}{ Males } \\
\hline \multicolumn{10}{|l|}{2004} \\
\hline May & $0.108 \pm 0.037$ & $0.145 \pm 0.050$ & - & 3.82 & 76 & $<0.001$ & - & - & - \\
\hline Jun & $0.062 \pm 0.044$ & $0.101 \pm 0.041$ & - & 5.00 & 87 & $<0.001$ & - & - & - \\
\hline Aug & $0.147 \pm 0.039$ & $0.274 \pm 0.060$ & - & 8.03 & 31 & $<0.001$ & - & - & - \\
\hline Sep & $0.130 \pm 0.046$ & $0.231 \pm 0.075$ & - & 6.60 & 56 & $<0.001$ & - & - & - \\
\hline \multicolumn{10}{|l|}{2005} \\
\hline Apr & $0.180 \pm 0.045$ & $0.254 \pm 0.061$ & - & 6.41 & 78 & $<0.001$ & - & - & - \\
\hline Jun & $0.101 \pm 0.040$ & $0.129 \pm 0.046$ & $0.090 \pm 0.059$ & 3.10 & 49 & 0.003 & 1.19 & 82 & 0.238 \\
\hline Aug & $0.099 \pm 0.036$ & - & $0.125 \pm 0.067$ & - & - & - & 1.94 & 59 & 0.058 \\
\hline Sep/Oct & $0.103 \pm 0.031$ & $0.222 \pm 0.044$ & $0.147 \pm 0.046$ & 12.83 & 48 & $<0.001$ & 3.76 & 40 & $<0.001$ \\
\hline \multicolumn{10}{|l|}{ Females } \\
\hline \multicolumn{10}{|l|}{2004} \\
\hline May & $0.128 \pm 0.047$ & $0.175 \pm 0.57$ & - & 4.50 & 87 & $<0.001$ & - & - & - \\
\hline Jun & $0.071 \pm 0.036$ & $0.107 \pm 0.038$ & - & 5.41 & 109 & $<0.001$ & - & - & - \\
\hline Aug & $0.166 \pm 0.049$ & $0.261 \pm 0.068$ & - & 5.87 & 39 & $<0.001$ & - & - & - \\
\hline Sep & $0.150 \pm 0.043$ & $0.259 \pm 0.060$ & - & 9.59 & 54 & $<0.001$ & - & - & - \\
\hline \multicolumn{10}{|l|}{2005} \\
\hline Apr & $0.178 \pm 0.051$ & $0.279 \pm 0.062$ & - & 9.39 & 72 & $<0.001$ & - & - & - \\
\hline Jun & $0.086 \pm 0.038$ & $0.151 \pm 0.050$ & $0.109 \pm 0.045$ & 5.71 & 31 & $<0.001$ & 2.95 & 107 & 0.004 \\
\hline Aug & $0.114 \pm 0.071$ & - & $0.123 \pm 0.071$ & - & - & - & 0.531 & 70 & 0.597 \\
\hline Sep/Oct & $0.132 \pm 0.051$ & $0.226 \pm 0.046$ & $0.158 \pm 0.037$ & 6.84 & 24 & $<0.001$ & 1.82 & 27 & 0.079 \\
\hline
\end{tabular}


Differences in growth rates among sites also should be considered in light of the relationship between initial size and growth (Fig. 4). Although little of the variation in the data is explained by the relationship as indicated by the modest $r^{2}$ values (0.003 to 0.138 ), all of the slopes were negative and all but 1 differed significantly $(\mathrm{p}<0.05)$ from 0 , indicating that growth rates were inversely related to initial size. Females, which were larger and grew faster than males (Table 1), were more abundant among the recaptured mummichogs at $\mathrm{D}_{\text {simple }}$ (males:females [m:f] $=0.822$ ) and $\mathrm{D}_{\text {complex }}(\mathrm{m}: \mathrm{f}=0.814)$ than at $\mathrm{O}_{\text {complex }}(\mathrm{m}: \mathrm{f}=1.416)$,

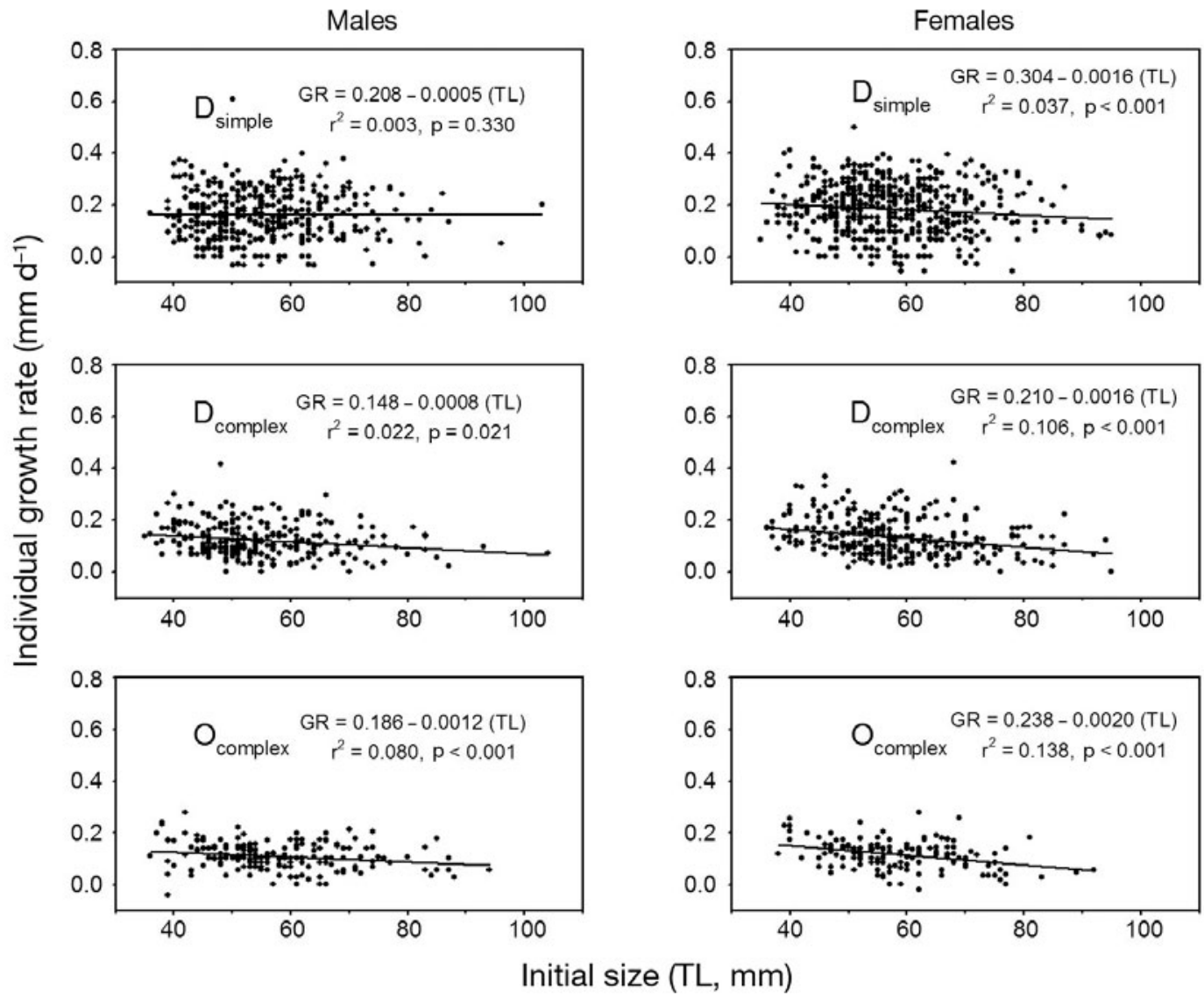

Fig. 4. Fundulus heteroclitus. Site-specific relationships between initial size of marked mummichogs at release and individual daily specific growth rates after 28 to $56 \mathrm{~d}$ at large

Table 5. Mean \pm SD values of water temperature, salinity, and dissolved oxygen (DO) measured at each site and 1-way ANOVA testing for differences among sites in each year; the numerator and denominator degrees of freedom used to test the significance of the F-value are both given. When the ANOVA showed a difference among means, the results of a posteriori Tukey HSD multiple comparisons indicated which means differed from one another. Means sharing a common superscript letter (a or b) did not differ significantly from one another $(\alpha=0.05)$

\begin{tabular}{|c|c|c|c|c|c|c|}
\hline \multirow[t]{2}{*}{ Parameter } & \multicolumn{3}{|c|}{ - Site } & \multicolumn{3}{|c|}{-1-way ANOVA } \\
\hline & $\mathrm{D}_{\text {complex }}$ & $\mathrm{D}_{\text {simple }}$ & $\mathrm{O}_{\text {complex }}$ & $F$ & df & $\mathrm{p}$ \\
\hline \multicolumn{7}{|l|}{2004} \\
\hline Temperature $\left({ }^{\circ} \mathrm{C}\right)$ & $26.2 \pm 5.0$ & $25.4 \pm 5.0$ & - & 0.32 & 1,54 & 0.572 \\
\hline Salinity (PSU) & $25.0 \pm 4.1$ & $24.7 \pm 5.0$ & - & 0.06 & 1,51 & 0.806 \\
\hline $\mathrm{DO}\left(\mathrm{mg} \mathrm{l}^{-1}\right)$ & $4.65 \pm 1.99$ & $4.79 \pm 1.37$ & - & 0.05 & 1,29 & 0.818 \\
\hline \multicolumn{7}{|l|}{2005} \\
\hline Temperature $\left({ }^{\circ} \mathrm{C}\right)$ & $22.6 \pm 7.1$ & $22.6 \pm 6.3$ & $24.8 \pm 7.6$ & 0.64 & 2,107 & 0.527 \\
\hline Salinity (PSU) & $18.6 \pm 3.5^{\mathrm{a}}$ & $21.2 \pm 3.7^{b}$ & $17.0 \pm 6.0^{\mathrm{a}}$ & 8.29 & 2,107 & $<0.001$ \\
\hline $\mathrm{DO}\left(\mathrm{mg} \mathrm{l}^{-1}\right)$ & $3.79 \pm 1.36^{\mathrm{a}}$ & $5.08 \pm 1.43^{\mathrm{b}}$ & $3.46 \pm 1.41^{\mathrm{a}}$ & 11.22 & 2,88 & $<0.001$ \\
\hline
\end{tabular}


where males were more abundant. Treating the sexes separately in comparisons of growth rates among sites reduced the effect of gender-based size bias in the field samples.

No significant site-specific differences in mean temperature, salinity, and DO were detected in the field during 2004. Mean salinity and DO were both significantly greater at $\mathrm{D}_{\text {simple }}$ than at the other 2 sites in 2005 (Table 5).

\section{Laboratory growth rate experiment}

Environmental conditions during the laboratory experiment reflected the seasonal variability typical of the early autumn (Fig. 5). Daily salinity measurements in the experimental tanks ranged from 12 to 27 , with a mean $\pm \mathrm{SD}$ of $22.4 \pm 5.2$. Water temperature and DO concentrations during the experiment were $26.3 \pm$ $2.1^{\circ} \mathrm{C}$ (range: 20.2 to $30.5^{\circ} \mathrm{C}$ ) and $5.3 \pm 0.4 \mathrm{mg} \mathrm{l}^{-1}$ (range: 4.5 to $6.3 \mathrm{mg} \mathrm{l}^{-1}$ ). Salinity, water temperature, and DO concentrations measured $(\mathrm{N}=22)$ at the 3 field sites $\left(D_{\text {simpler }} D_{\text {complex }}\right.$ and $\mathrm{O}_{\text {complex}}$ ) at the same time of year (September to October 2005) were $20.6 \pm$ 3.0 (range: 7.7 to 25.7 ), $25.8 \pm 1.8^{\circ} \mathrm{C}$ (range: 17.5 to $30.8^{\circ} \mathrm{C}$ ) and $3.5 \pm 2.1$ $\mathrm{mg} \mathrm{l}^{-1}$ (range: 1.5 to $6.4 \mathrm{mg} \mathrm{l}^{-1}$ ), respectively. The only substantial difference between these environmental parameters in the laboratory and field was in DO concentration, which was lower on average and was more variable in the field. This was not surprising given that the experimental tanks in the laboratory were constantly aerated.
Results of the analyses of size and growth data from the 'common garden' experiment in which mummichogs from $\mathrm{D}_{\text {complex }}$ and $\mathrm{D}_{\text {simple }}$ were held in the laboratory for $42 \mathrm{~d}$ under identical conditions are shown in Table 6. A 3-way ANOVA on mean initial sizes of mummichogs in the experiment detected no significant differences except where expected in the factor Size as a result of using 2 distinct size classes of mummichogs from each site. Thus, there was no unintended bias associated with mean initial size introduced at the start of the experiment.

In contrast to the field growth data, there was no evidence of variance heterogeneity in the growth responses of mummichogs to Site $\left(F_{11,11}=0.900, \mathrm{p}=\right.$ $0.865)$, Size $\left(F_{11,11}=0.464, \mathrm{p}=0.219\right)$, or Ration $\left(F_{11,11}=\right.$ $0.379, \mathrm{p}=0.123$ ). Mean growth rates in the laboratory were not significantly affected by Site either as a main effect or in interaction with any other factor, but there was a significant interaction between Size and Ration (Table 6). It is clear that mummichogs from the $\mathrm{D}_{\text {simple }}$

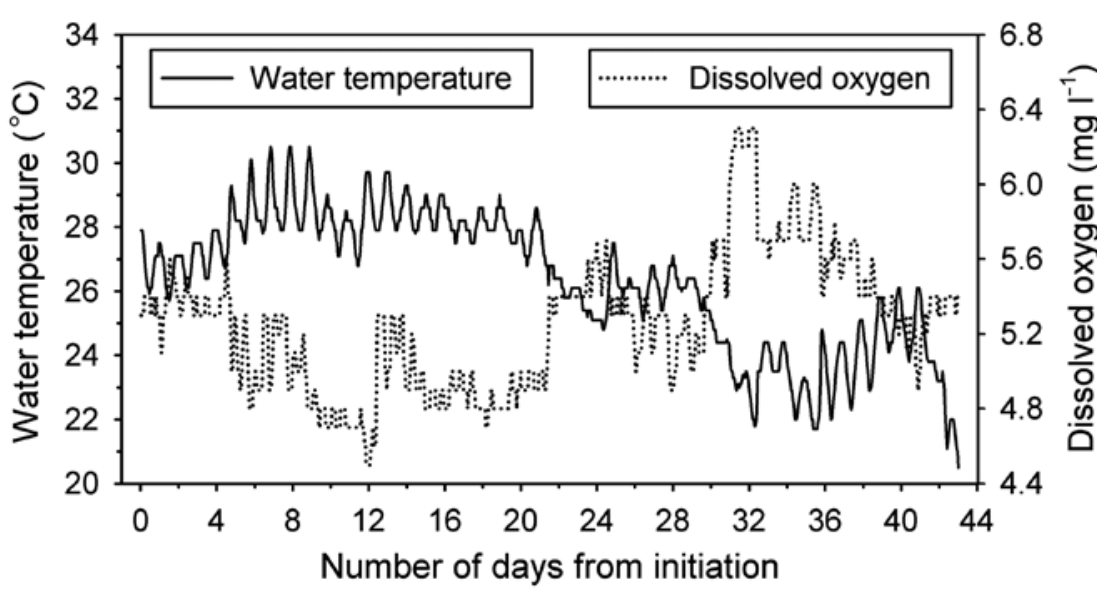

Fig. 5. Diel and seasonal variation in water temperature and dissolved oxygen concentrations in experimental tanks during the laboratory growth experiment (12 September to 24 October 2005)

Table 6. Fundulus heteroclitus. ANOVA testing for differences in mean initial sizes (TL, $\mathrm{mm}$ ) and daily absolute growth rates (GR, $\mathrm{mm} \mathrm{d}^{-1}$ ) of mummichogs among treatment combinations in the laboratory growth experiment. The 3 factors in the experiment were: Site $=\mathrm{D}_{\text {simple }}$ or $\mathrm{D}_{\text {complex }}$, Size $=$ initial size class $(40-50$ or $55-65 \mathrm{~mm}$ TL), and Ration = daily food ration $(10$ or $30 \%$ of body mass). Experimental tanks were replicates $(\mathrm{N}=24)$, and the average values from the surviving mummichogs (8 to 10 individuals) in each tank were the response variables

\begin{tabular}{|c|c|c|c|c|c|c|c|}
\hline \multirow{2}{*}{ Source of variation } & \multirow{2}{*}{$\mathrm{df}$} & \multicolumn{3}{|c|}{ - Initial size } & \multicolumn{3}{|c|}{-Daily GR - } \\
\hline & & MS & F-ratio & $\mathrm{p}$ & MS & F-ratio & $\mathrm{p}$ \\
\hline Site & 1 & 4.0838 & 3.72 & 0.072 & 0.0016 & 3.28 & 0.089 \\
\hline Size & 1 & 1262.9504 & 1149.87 & $<0.001$ & 0.0018 & 3.65 & 0.074 \\
\hline Ration & 1 & 0.0704 & 0.06 & 0.803 & 0.3349 & 663.03 & $<0.001$ \\
\hline Site $\times$ Size & 1 & 1.0004 & 0.91 & 0.354 & 0.0002 & 0.42 & 0.526 \\
\hline Site $\times$ Ration & 1 & 0.0104 & 0.01 & 0.924 & 0.0003 & 0.64 & 0.434 \\
\hline Size $\times$ Ration & 1 & 0.0104 & 0.01 & 0.924 & 0.0141 & 27.97 & $<0.001$ \\
\hline Site $\times$ Size $\times$ Ration & 1 & 1.1704 & 1.07 & 0.317 & 0.0002 & 0.46 & 0.508 \\
\hline Error (Residual) & 16 & 1.0983 & & 0.0005 & & & \\
\hline
\end{tabular}




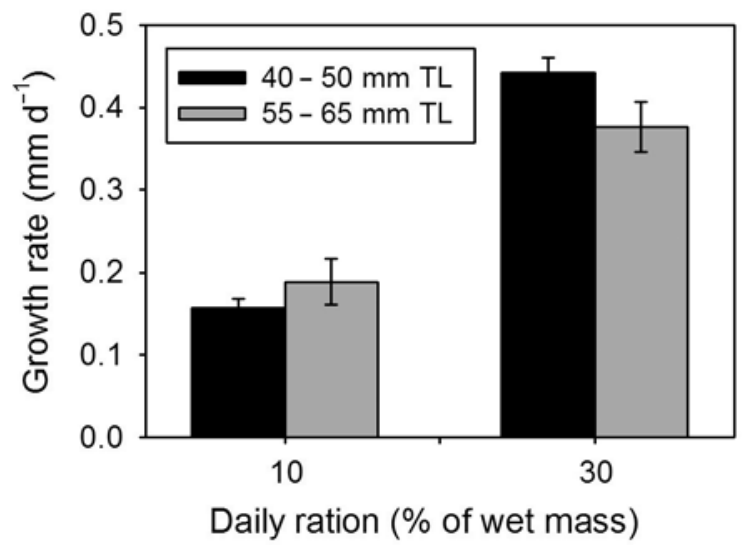

Fig. 6. Fundulus heteroclitus. Interaction between initial mummichog size $(40-50,55-65 \mathrm{~mm}$ TL) and daily food ration (10 and $30 \%$ of wet mass) in the laboratory growth experiment. Response variables are average daily growth rates of individual mummichogs surviving $42 \mathrm{~d}$ in each experimental unit (tank). Error bars are \pm SD about the mean and each is based on $\mathrm{N}=6$ tanks

site did not grow faster than conspecifics from the $\mathrm{D}_{\text {com- }}$ plex site when held under the same physical conditions and food rations. However, the significant Size $\times$ Ration interaction indicated a size-specific difference in response to ration size (Fig. 6). Subsequent $t$-tests (using pooled variance estimates) showed that individuals in the larger size class grew significantly $\left(t_{10 \mathrm{df}}=\right.$ 2.56, $\mathrm{p}=0.028$ ) faster than those in the smaller size class on a $10 \%$ daily food ration, but mummichogs in the smaller size class grew faster on the $30 \%$ food ration $\left(t_{10 \mathrm{df}}=4.62, \mathrm{p}<0.001\right)$.

\section{DISCUSSION}

\section{Field recapture rates}

The high rates of recapture of free-ranging marked mummichogs in this study (averaging 19\%) are consistent with observations from more northern latitudes within the species' geographic range along the Atlantic coast of North America (e.g. Lotrich 1975, Teo \& Able 2003, Skinner et al. 2005). This confirms that individuals of both the northern (macrolepidotus) and southern (heteroclitus) sub-species of Fundulus heteroclitus have a general tendency to exhibit a small $(<1 \mathrm{~km})$ home range. All 3319 recaptured individuals in this study were recovered at the same sites where they were originally marked and released, so there was no evidence of inter-site movement of marked mummichogs even between the nearest sites $\left(\mathrm{O}_{\text {complex }}\right.$ and $\mathrm{D}_{\text {simple), }}$, which were about $1 \mathrm{~km}$ apart.

Differences in recapture rates among sites (Table 2) suggested that landscape complexity may have played a role in recapture success. Recapture rates were inversely related to the complexity of tidal channel networks. In 2004, the proportion of marked individuals recaptured at $\mathrm{D}_{\text {simple }}(36.4 \%)$ was more than twice that at $\mathrm{D}_{\text {complex }}(15.7 \%)$. Recaptures were lower in 2005 $\left(18.7 \%\right.$ at $\mathrm{D}_{\text {simple }}$ and $11.8 \%$ at $\left.\mathrm{D}_{\text {complex }}\right)$ as a consequence of allocating sampling time to a third marking site $\left(\mathrm{O}_{\text {complex }}, 15.0 \%\right.$ recaptured $)$, and delaying attempts to recapture fish for a minimum of $12 \mathrm{~d}$ following the release of marked individuals (in 2004, the first attempts to recapture fish occurred within $6 \mathrm{~d}$ after marking). However, the proportion of marked individuals recaptured still differed significantly $\left(\chi^{2}=58.31, \mathrm{df}=2, \mathrm{p}<\right.$ $0.001)$ across sites, with the lowest and highest recapture rates at $\mathrm{D}_{\text {complex }}$ and $\mathrm{D}_{\text {simple, }}$ respectively (Table 2 ). Recapture rates at $\mathrm{O}_{\text {complex }}$ were intermediate and differed significantly from both $\mathrm{D}_{\text {complex }}\left(\chi^{2}=11.13, \mathrm{df}=1\right.$, $\mathrm{p}<0.001)$ and $\mathrm{D}_{\text {simple }}\left(\chi^{2}=15.01, \mathrm{df}=1, \mathrm{p}<0.001\right)$. There are several plausible explanations for the variation in recapture success among sites, including sitespecific differences in mortality rates, size of home ranges, or variation in effectiveness of sampling among tidal channel networks with different levels of complexity (i.e. drainage density, Fig. 1). It is beyond the scope of this study to distinguish among these alternative explanations, but more complex channel networks certainly provide mummichogs (and their predators) with more options in terms of shelter (i.e. tidal refugia) and foraging opportunities (i.e. intertidal access) as well as pathways and choices for movement within the ecosystem; all of these factors could conceivably influence patterns of survival, movement, and growth.

\section{Field growth rates}

Short-term (28 to 56 d) field growth rates of recaptured mummichogs varied among sites and were also inversely related to landscape complexity (Table 4). Differences in the average initial size of marked individuals among sites could have contributed to spatial variation in growth but, given the inverse relationship between size and growth (Fig. 4), this should have resulted in more rapid growth rates at the complex sites where initial sizes of marked mummichogs tended to be smaller. The more rapid growth rates of mummichogs at $\mathrm{D}_{\text {simple }}$ (Table 4 ) occurred regardless of differences in average initial size, and so an alternative explanation is required.

Differences in salinity and DO between upper and lower reaches of Georgia tidal creeks have been observed (Hackney et al. 1976) and can affect the growth rates of fishes (e.g. Stierhoff et al. 2006). Mean salinity and DO were greater at $\mathrm{D}_{\text {simple }}$ than at the other sites in 2005 (Table 5), but differences were not 
detectable in 2004, nor were they large enough to account for the consistent difference in mean growth rates between $\mathrm{D}_{\text {simple }}$ and $\mathrm{D}_{\text {complex }}$.

Spatial variation in growth rates of fishes in both freshwater streams and tidal estuarine systems have been associated with site-specific food availability (e.g. Hurst \& Abookire 2006, Arnekleiv et al. 2006), density (e.g. Lobón-Cerviá 2005), and the presence of predators (e.g. Fraser \& Gilliam 1992). It should be noted that observations on field growth rates in the present study came from only 3 sites that were characterized by different levels of landscape complexity as defined in Fig. 1. Because there were no true replicates of any level of landscape complexity (i.e. groups of multiple sites with the same levels of landscape complexity), the field observations from this study cannot be extended with any statistical reliability beyond the sites examined here.

Given that standing stock biomass of mummichogs and other tidal marsh nekton on Sapelo Island tend to be greater at sites with more complex channel networks (Kneib 2003), the present results show that landscape-related variation in production is not driven by differences in mean individual growth rates, but perhaps by differences in relative abundance (i.e. complex intertidal drainage networks support more individuals); a similar observation of a positive relationship between intertidal channel complexity and abundance also has been reported for juvenile penaeid shrimp in Georgia estuaries (Webb \& Kneib 2002).

Predators can influence both density and growth rate of prey species, but the proposed mechanisms of predator influence often vary with specific situations. These may include competitive release (e.g. Craig et al. 2006), behavior/activity modification (e.g. Fraser \& Gilliam 1992), and growth-selection (e.g. Takasuka et al. 2007). Furthermore, whether growth-selective predation favors individuals that express slow or rapid growth remains unresolved (e.g. Sundström et al. 2005, Takasuka et al. 2007, Biro \& Post 2008). It is possible that mummichogs at the $\mathrm{D}_{\text {simple }}$ site were exposed to a broader range of piscivores from the adjacent open estuary (Fig. 1) than those in the upper reaches of the Duplin River drainage $\left(\mathrm{D}_{\text {complex }}\right)$, and the slower-growing individuals were culled selectively from the population at the more exposed site. However, such an explanation seems inconsistent with the observation that the recovery rate of marked mummichogs was greater at $\mathrm{D}_{\text {simple }}$ than at $\mathrm{D}_{\text {complex}}$.

\section{Differences between laboratory and field growth rates}

Growth responses of mummichogs in the laboratory compared to those observed at the field sites provided some insights into the potential and realized scope for growth in this species. The range of growth rates observed in the laboratory (Fig. 6) encompassed growth rates observed in the field populations (Table 4). Absolute growth rates $\left(\mathrm{mm} \mathrm{d}^{-1}\right)$ of free-ranging mummichogs (overall mean \pm SD: $0.155 \pm 0.083$ ) tended to be closest to those observed in the laboratory at a daily ration of $10 \%$ wet body mass $(0.173 \pm 0.026)$ than at $30 \%(0.409 \pm 0.042)$. This suggests that much of this species' scope for growth is unrealized, and growth of mummichogs may be resource limited even in the productive tidal marsh environment. Weisberg \& Lotrich (1982) used field experiments to show that intertidal resources were an important energy source for mummichog populations, suggesting that access to the intertidal marsh was important.

Early observations on Sapelo Island relating the complexity of tidal drainage networks to marsh elevation and distance to open water (Ragotzkie 1959) were confirmed by previously published measurements of elevation above mean low water at the present study sites (Kneib 2003): $\mathrm{D}_{\text {simple }}(+221$ to $+225 \mathrm{~cm}), \mathrm{O}_{\text {complex }}$ $(+194$ to $+197 \mathrm{~cm})$, and $\mathrm{D}_{\text {complex }}(+155$ to $+189 \mathrm{~cm})$. In the present study, growth was greater at the site highest in elevation $\left(\mathrm{D}_{\text {simple }}\right)$, which should have provided less access to intertidal marsh resources than either of the more frequently flooded sites. This apparent inconsistency between the current findings and those of Weisberg \& Lotrich (1982) suggests that some factor(s) operating within the creek channels affected growth rates in the present study.

The location of $\mathrm{D}_{\text {simple }}$ at the mouth of the Duplin River means that the mummichog population there has access to a larger body of water (Fig. 1), and perhaps a different suite of food resources that support more rapid adult growth rates. For example, epibenthic mysids (e.g. Neomysis americana), which are often abundant at $D_{\text {simple }}$ but absent from the other sites sampled in this study (pers. obs.), are important in the diets of many estuarine fishes (Heard et al. 2006). Also, mummichogs residing in relatively simple tidal drainage networks may expend less energy in moving within the landscape than those in complex drainage networks, which present more choices (channel bifurcations and sinuous pathways) in traversing the system during daily tidal forays. The apparent inverse relationship between landscape complexity and the proportion of marked individuals recaptured suggests that mummichogs in simple tidal channel networks may not disperse as widely as those in more complex environments. If food is more abundant in creek channels adjacent to larger bodies of water, there may be little reason for a local population of mummichogs to expend energy foraging extensively on the intertidal marsh surface. In any case, the marshes at sites adjacent to large channels are 
likely less accessible to fish, at least in Georgia, where such sites are characterized by less complex channel networks and higher elevations (Ragotzkie 1959, Frey \& Basan 1978). Ross \& Lancaster (2002) also suggested that abundant food resources could explain minimal movements of fishes in the surf zones. However, as in their study, fish diets were not determined here, so this hypothesis remains to be tested.

A significant interaction between the experimental factors of fish Size and daily Ration was not surprising. The relatively higher growth rates shown by smaller fish fed a larger daily ration (Fig. 6) may be explained by size-specific differences in the allocation of energy to maintenance and growth. The low ration $(10 \%$ of wet mass $\mathrm{d}^{-1}$ ) likely limited the scope for growth by providing each size class with a relatively small measure of energy intake above that needed to satisfy basic metabolic needs. At the higher daily ration of $30 \%$ wet mass, the normally greater scope for growth in the smaller size class (Brett \& Groves 1979) of mummichogs was more fully expressed.

Findings of the 'common-garden' laboratory experiment unequivocally demonstrated that the higher growth rates observed in field populations of mummichogs from $\mathrm{D}_{\text {simple }}$ compared to those from $\mathrm{D}_{\text {complex }}$ did not persist when individuals from the 2 sites were grown under identical conditions for $42 \mathrm{~d}$ (Table 6). Therefore, the hypothesis of spatial variation in genotypes as an explanation for the observed variation in growth rates among mummichog populations in complex and simple marsh channel networks on Sapelo Island is rejected. The present study was not designed to assess the generality of the field observations linking landscape complexity to growth, nor was the lab experiment designed to test the hypothesis that environmentally-induced differences in gene expression (i.e. gene switching) contribute to variation in growth rates across the tidal marsh landscape. Additional aspects of a potential connection between landscapelevel variation and genomic-level responses (via gene expression) in mummichog populations remain to be explored.

Acknowledgements. This project could not have been completed without the able assistance of a dedicated group of technicians, including T. Repicky, J. Plunket, C. Ellinwood, and J. Kneib, who captured, measured, and tagged thousands of mummichogs in the field, and carefully monitored and maintained the experimental conditions in the laboratory experiment. Financial support for this research was provided by the National Science Foundation (grant nos. OCE-0308877 and DEB-9629621). Any opinions, findings, and conclusions or recommendations expressed here are those of the author and do not necessarily reflect the views of the National Science Foundation or any other government or private organization with which the author is affiliated. This is Contribution No. 976 of the University of Georgia Marine Institute.

\section{LITERATURE CITED}

Able KW, Hagan SM, Brown SA (2006) Habitat use, movement, and growth of young-of-the-year Fundulus spp. in southern New Jersey salt marshes: comparisons based on tag/recapture. J Exp Mar Biol Ecol 335:177-187

- Adams CE, Huntingford FA (2004) Incipient speciation driven by phenotypic plasticity? Evidence from sympatric populations of Arctic charr. Biol J Linn Soc 81:611-618

Adams CE, Hamilton DJ, McCarthy I, Wilson AJ and others (2006) Does breeding site fidelity drive phenotypic and genetic sub-structuring of a population of Arctic charr? Evol Biol 20:11-26

> Agrawal AA, Ackerly DD, Adler F, Arnold AE and others (2007) Filling key gaps in population and community ecology. Front Ecol Environ 5:145-152

Arnekleiv JV, Finstad AG, Rønning L (2006) Temporal and spatial variation in growth of juvenile Atlantic salmon. J Fish Biol 68:1062-1076

Bigelow HB, Schroeder WC (1953) Fishes of the Gulf of Maine. Fish Bull 74. Fish Bull Fish Wildl Serv 53:162-164

Biro PA, Post JR (2008) Rapid depletion of genotypes with fast growth and bold personality traits from harvested fish populations. Proc Natl Acad Sci USA 105:2919-2922

Brett JR, Groves TDD (1979) Physiological energetics. In: Hoar WS, Randall DJ, Brett JR (eds) Fish physiology. Academic Press, London, p 279-352

Craig JK, Burke BJ, Crowder LB, Rice JA (2006) Prey growth and size-dependent predation in juvenile estuarine fishes: experimental and model analyses. Ecology 87:2366-2377

Fraser DF, Gilliam JF (1992) Nonlethal impacts of predator invasion: facultative suppression of growth and reproduction. Ecology 73:959-970

Frey RW, Basan PB (1978) Coastal salt marshes In: Davis RA Jr (ed) Coastal sedimentary environments. Springer-Verlag, New York, NY, p 101-169

Hackney CT, Burbanck WD, Hackney OP (1976) Biological and physical dynamics of a Georgia tidal creek. Chesap Sci 17:271-280

Heard RW, Price WW, Knott DM, King RA, Allen DM (2006) A taxonomic guide to the mysids of the South Atlantic Bight. NOAA Professional Paper NMFS 4. Available at http:// spo.nmfs.noaa.gov

Hurlbert SH (1984) Pseudoreplication and the design of ecological field experiments. Ecol Monogr 54:187-211

Hurst TP, Abookire AA (2006) Temporal and spatial variation in potential and realized growth rates of age- 0 year northern rock sole. J Fish Biol 68:905-919

Kneib RT (1997) The role of tidal marshes in the ecology of estuarine nekton. Oceanogr Mar Biol Annu Rev 35: $163-220$

> Kneib RT (2003) Bioenergetic and landscape considerations for scaling expectations of nekton production from intertidal marshes. Mar Ecol Prog Ser 264:279-296

- Kneib RT, Craig AH (2001) Efficacy of minnow traps for sampling mummichogs in tidal marshes. Estuaries 24:884-893

> Lobón-Cerviá J (2005) Spatial and temporal variation in the influence of density dependence on growth of stream-living brown trout (Salmo trutta). Can J Fish Aquat Sci 62: 1231-1242

> Lotrich VA (1975) Summer home range and movements of Fundulus heteroclitus (Pisces: Cyprinodontidae) in a tidal creek. Ecology 56:191-198

> Morin RP, Able KW (1983) Patterns of geographic variation in the egg morphology of the fundulid fish, Fundulus heteroclitus. Copeia 1983:726-740

Ragotzkie RA (1959) Drainage patterns in salt marshes. In: 
Ragotzkie RA, Pomeroy LR, Teal JM, Scott DC (eds) Proc Salt Marsh Conf. Marine Institute of the University of Georgia, Athens, GA, p 22-25

Ross SW, Lancaster JE (2002) Movements and site fidelity of two juvenile fish species using surf zone nursery habitats along the southeastern North Carolina coast. Environ Biol Fishes 63:161-172

Skinner MA, Courtenay SC, Parker WR, Curry RA (2005) Site fidelity of mummichogs (Fundulus heteroclitus) in an Atlantic Canadian Estuary. Water Qual Res J Can 40:288-298

Stierhoff KL, Targett TE, Miller K (2006) Ecophysiological responses of juvenile summer and winter flounder to hypoxia: experimental and modeling analyses of effects on estuarine nursery quality. Mar Ecol Prog Ser 325: 255-266

Sundström LF, Lõhmus M, Devlin RH (2005) Selection on increased intrinsic growth rates in coho salmon, Oncor hynchus kisutch. Evolution 59:1560-1569

Takasuka A, Aoki I, Oozeki Y (2007) Predator-specific growth-selective predation on larval Japanese anchovy Engraulis japonicus. Mar Ecol Prog Ser 350:99-107

Editorial responsibility: Robert Feller,

Columbia, South Carolina, USA
Teo SLH, Able KW (2003) Habitat use and movement of the mummichog (Fundulus heteroclitus) in a restored salt marsh. Estuaries 26:720-730

Turner MG (1989) Landscape ecology: the effect of pattern on process. Annu Rev Ecol Syst 20:171-197

Wadsworth JR Jr (1980) Geomorphic characteristics of tidal drainage networks in the Duplin River system, Sapelo Island, Georgia. PhD dissertation, University of Georgia, Athens

Webb SR, Kneib RT (2002) Abundance and distribution of juvenile white shrimp Litopenaeus setiferus within a tidal marsh landscape. Mar Ecol Prog Ser 232:213-223

Webb SR, Kneib RT (2004) Individual growth rates and movement of juvenile white shrimp (Litopenaeus setiferus) in a tidal marsh nursery. Fish Bull 102:376-388

Weisberg SB, Lotrich VA (1982) The importance of an infrequently flooded intertidal marsh surface as an energy source for the mummichog Fundulus heteroclitus: an experimental approach. Mar Biol 66:307-310

Zar JH (1996) Biostatistical analysis (3rd edn). Prentice Hall, Upper Saddle River, NJ

Submitted: December 1, 2008; Accepted: April 17, 2009

Proofs received from author(s): June 17, 2009 